\title{
Pölöskei Ferenc Kossuth és az államforma kérdése a szabadságharc idején
}

A modern polgári jogállam alkotmányjogi-jogelméleti alapvetése a felvilágosodás kiemelkedő gondolkodóinak munkásságában lelhető fel. Lényegét az államhatalmi ágak megosztásában, egyensúlyában és a politikai, emberi, személyes szabadságjogok teljességének biztosításában összegezték. Eszerint a demokratikus jogállam formája alkotmányos monarchia vagy köztársaság lehet. Ennek a jogállamiságnak a szabatos megfogalmazásáig a XIX. századi Magyarországon, építve a felvilágosodás, a modern alkotmányosság úttörőire és klasszikusaira lépésről lépésre, fokozatosan és sajátos új nyomvonalon - Kossuth ért el, 1851. évi Alkotmánytervében. Ennek a hosszú és tekervényes útnak a teljes áttekintését nem tekinthetem feladatomnak, inkább csak a végkifejlet néhány jellemző vonását villanthatom fel.

Kossuth figyelmét elsősorban az angol, a francia, a norvég, a belga és az amerikai alkotmány ragadta meg. Németül, franciául jól tudott, s így olvashatta a müveket, alkotmányokat, angolul pedig börtönévei alatt tanult meg, így az amerikai alkotmányt eredeti szövegében is tanulmányozhatta. Franklin életrajza már 1818-ban megjelent az Erdélyi Múzeumban ifj. Szilágyi Ferenc fordításában, Bajza József pedig 1832-ben tette közzé Washingtonról szóló írását.

Európában a monarchia intézményét és vele együtt a király, a császár, a cár rendkívüli hatalmát a közép- és a kora újkorban, századokon át misztikus hatalmaktól eredeztették. Számukra elsősorban a végrehajtó hatalom és a hadsereg vezetése terén szinte kizárólagos jogokat biztosítottak, ám a törvényhozásban és a bíróságok müködésében is érvényesíthették akaratukat. Az abszolút monarchák kora ez, s rajtuk csak kevés helyen, ritka esetekben ütöttek rést. Ide sorolhatók Angliában a Cromwell nevéhez kötődő törvények, amikor elfogadták például az 1647-ben kidolgozott, majd több vonatkozásban módosított Agreement of the people-t, a nép szerződését tartalmazó okmányt. Eszerint az alkotmányozó hatalom a népé, s a törvényhozás jellegét, felépítését, szerkezetét is megalkotja. A lényegi, tartalmi változást jelzi később az 1679-ben elfogadott Habeas Corpus Act, majd a 10 évvel későbbi, 1689. évi Declaration of Rights, illetve a Bill of Rights, amelyek a személyes szabadság védelmét, valamint a királyi hatalom korlátozását, illetve a polgárok politikai, emberi jogait biztosították.

Hasonló jelenségeket figyelhetünk meg a németalföldi tartományok esetében is. Hosszú időn át sajátos, önálló történelmi utat járt Svájc. Miután a kantonok és a szabad városok kiállták a külső fenyegető veszélyeket, az 1648-as vesztfáliai béke önálló, szuverén államnak ismerte el a már 13-ra bővült kanton szövetségét. Kimondotta Svájc „örök időkre szóló” semlegességét is.

A polgári jogfejlődés teljességét, klasszikusnak tekinthető következetes útját a XVIII. század végi francia forradalom képviseli, mert romba döntötte az alapvető feudális intézményeket $\mathrm{s}$ a gazdasági, politikai igények szerint újakat alkotott. 1791. szeptember 3-án megteremtette a törvények törvényét, az írott alkotmányt, amelyet azután mintegy 14 követett. Az 1791. évi alkotmány a hatalmi ágak megosztását tartalmazta, a szuverenitást a nemzettől eredeztette és gyakorlásával még az „örökletes” királyt és az egykamarás Nemzetgyülést bízta meg. Ezen belül a Nemzetgyülést illette meg a törvényhozás joga, a király pedig a végrehajtó hatalom élén állt. Ez a struktúra azonban később több ízben is változott. 1792-ben az ország államformája a köztársaság lett. Ezt az 1793. évi jakobinus alkotmány is rögzítette, amely a népszuverenitás elve alapján a végrehajtó hatalmat közvetlenül a nép kezébe kívánta helyezni. 
A polgári alkotmányjogi fejlődés útját áttekintve nem mellőzhetjük az 1831. évi belga alkotmány felidézését, mert hosszú ideig a polgári átalakulást kereső országok és politikusaik számára, különösen az 1848. évi európai forradalmak idején vagy később a balkánon is, szinte követendő példának számított. Keletkezése szorosan összekapcsolódott az 1830. júliusi párizsi forradalommal, melynek hatására Belgium kiszakadt a nagyhatalmak által diktált holland uralomból és önállóvá vált. Az ideiglenes kormány 1830. október 4-én deklarálta függetlenségét az alkotmányos monarchia keretében, majd a választások útján életre hívott 200 tagú Nemzeti Kongresszus 1831. február 7-én elfogadta az alkotmányt. Eszerint a törvényhozó hatalmat a parlament két háza - a képviseleti kamara és a szenátus - gyakorolja. A végrehajtó hatalom a parlamentnek felelös kormányt illeti. A király természetesen részt vesz a végrehajtó hatalom munkájában, de intézkedéseihez miniszteri ellenjegyzés szükséges. Az alkotmány részletezte a bíróságok feladatkörét, a büntetőjogi esetekben elrendelte az esküdtszékek felállítását.

Az angol, dán, holland, svéd, norvég, belga monarchia is azért maradhatott fenn, mert nem ragaszkodott hagyományos kormányzati privilégiumaihoz, s miután az újat kereső, kutató törekvések nem az államforma megváltoztatására irányultak, megszülethettek az alkotmányos monarchiák. Mellettük születtek és éltek a köztársaságok.

A nyugat-európai polgári átalakulás által felvillantott politikai állomások természetesen évszázadokra kiterjedő eszmei gondolatvilágra, irodalomra építve jöttek létre. Ezúttal természetesen vázlatosan - csupán Montesquieu nézeteit, illetve e témával összefüggő egyes elemeit elevenítjük fel.

Montesquieu Locke nyomán indult, amikor a hatalmi ágak megosztását és egyensúlyát rendszerbe fonta. Ezen belül a törvényhozó hatalom szerkezete és müködése került figyelmének középpontjába is. Ennek alapján megkülönböztette egymástól államformáikat is; ezek köztársasági, monarchikus vagy despotikusak lehetnek. Az abszolút monarchia viszonyai közepette különös gonddal foglalkozott a köztársasági államformával. Elemzi a polgár két arcát is a demokratikus köztársaságban, hiszen uralkodó, ám alattvaló is egyben. Egyfelől ugyanis alanyi jogon része a hatalom egészének, másfelől azonban alattvalója a polgárokból álló hatalomnak. Kiemelkedő hely jut ezért a nép által életre hívott állami főhatalomnak. Montesquieu a 18. század első felében nagyívű írásmüveivel, gondolatainak merész vonulataival vált ismertté. A legnagyobb visszhangot élete főművével érte el; korábbi írásai is mintegy felkészülését jelzik $A$ törvények szelleméröl címü müvének megírásához, végső formába öntéséhez.

A társadalmi átalakulás és az önrendelkezés, a polgári jogállam programjának körvonalai - a már jelzett előzményekre építve - 1847 tavaszára már kirajzolódtak Kossuth elképzeléseiben. 1847. március 15-én a reformellenzék elfogadta az ő erre irányuló javaslatát, majd a júniusi konferencia jóváhagyta az Ellenzéki Nyilatkozat szövegét, amelyet az ő munkálatai alapján egy bizottság - Kossuth, Eötvös, Pulszky Ferenc, Szemere Bertalan, Teleki László és Deák véglegesített. A nyilatkozat az ismert nemzeti sérelmek felsorakoztatásán túl alkotmányos és felelős kormányzást, a sajtó, az egyesülés szabadságát, Magyarország és Erdély egyesítését, a közteherviselés bevezetését, a törvény előtti egyenlőséget, a kötelező örökváltságot, az ősiség eltörlését is tartalmazta. Kossuthnak a Pest megyei követválasztásra elkészített programja több ponton - például a külügyi, illetve a büntetőbíráskodás és a jobbágyviszonyok terén bővítette, részletezte az Ellenzéki Nyilatkozatot.

$\mathrm{Az}$ utolsó rendi országgyülésen a reformellenzék került ugyan eröfölénybe, de a sok huzavona, a szokványos sérelmi politika vagy a válaszfelirati vita nemcsak elodázta, hanem kérdésessé is tette Kossuth akkori társadalmi és nemzeti programjának elfogadtatását is. 
Ébrentartásáról elsősorban Kossuth gondoskodott, mert a mellékutakról újra meg újra visszavezette a vitát a fökérdések nyomvonalára.

1848 tavasza így nem érte váratlanul az országgyülést. A párizsi, a bécsi és a pesti forradalmak hatására napok alatt végső formába öntötte és elfogadta a polgári jogállamiság legföbb pilléreit tartalmazó törvényeket.

A pozsonyi rendi országgyülés által elfogadott törvények és a Batthyány-kormány megalakulása után Kossuth szerepe immár nemcsak az alsótáblában, hanem az ország életében is meghatározóvá vált. Övé lett a kulcsszerep, s ez a forradalom későbbi szakaszaiban tovább erösödött. Elérkezett az az idő, amikor a politikus gondolatai, tervei, tettvágya elől elhárultak a nagyobb belső akadályok, s megnyílt az út az alkotmányos monarchia megvalósítása felé. S úgy tủnt: további céljait már könnyüszerrel elérheti, holott számos akadály tornyosult eléje.

Az 1848. április 11-én szentesített törvények széttörték a feudalizmus épületét, megalkották a népképviseleti országgyülést és a neki felelős magyar minisztériumot, továbbá a legfontosabb politikai szabadságjogokat.

A rendi alkotmányt, országgyülést 1848-ban felváltó új törvényhozó hatalom, a népképviseleti országgyülés már nem a nemesi vármegye követeit tömörítette, hanem az új választójog és választási rendszer szerint megválasztott képviselöket. Az 1848. 5. tc. meghatározta az ismert országos képviselői választói jogosultságot és a választhatóságot. A végrehajtó hatalom síkján, az 1848. évi 3. tc. a „Független magyar felelős minisztérium alakításáról” rendelkezett. Az 1848. évi szentesített törvények közül azonban feltünő módon hiányzik a bírói hatalom pontos meghatározása, szerkezetének, önállóságának szabatos leírása, holott éppen az 1843-1844. évi országgyülés idején már elkészült a modern, polgári büntető törvénykönyv tervezete.

Bőven maradt persze még más tennivaló is az új rend teljes körü megteremtése és működése terén, erre azonban az adott viszonyok közepette nem kerülhetett sor. Ez a körülmény azonban nem csökkenti az említett törvények jelentőségét, hiszen éppen országos jellegük miatt a megoldatlanul hagyott vagy felemásan szabályozott kérdések széles körére is hatottak. Megemlíthetjük itt a jobbágyfelszabadítást, a megyerendszert, a nemzetiségi kérdést és Magyarország helyét az alkotmányos monarchia rendszerében. A jobbágyfelszabadítás ugyanis csak az úrbéres jobbágyokra terjedt ki, de nem érintette például a parasztok által használt maradvány- és irtásföldeket vagy a majorsági zsellérkérdést. A megyék polgári átalakítása is függőben maradt, mert itt - az országos képviselőválasztásokkal ellentétben nem érvényesítették a népképviseleti elvet, de a régi feudális megye sem maradt fenn változatlanul. Az Ausztria és Magyarország közötti viták pedig a külpolitikára, a hadseregre és a gazdaságra egyaránt kiterjeszkedtek.

A törvényhozó és a végrehajtó hatalmat taglaló törvények mellett azonban számos olyat találunk még, amelyek a polgári alkotmányosság megalapozását tartalmazták. Közülük kiemeljük A közös teherviselésröl szóló. 8. tc.-et, a papi tized megszüntetését tartalmazó 13. tc.-et, az ösiség eltörlését rögzítő 15. tc.-et, az 1848. évi 18. tc.-et a sajtószabadságról. A sort természetesen tovább folytathatnánk.

A magyar álláspont Kossuth egyeztető politikáján alapult, amely ekkor az időhúzásban, a várakozó taktikában öltött testet. A két fél álláspontja azonban szemlátomást távolodott egymástól, s egyre kevesebb esély maradt az egyezség számára. Mindezzel együtt immár az is kitünt, hogy az áprilisi törvények a pillanat adta körülmények közepette születhettek meg, ezért eleve törékenyeknek bizonyultak.

Az úgynevezett magyar jakobinus mozgalom (Martinovics, Hajnóczy, Öz Pál) megsemmisítése után a köztársasági eszme sem a reformkorban, sem 1848-ban nem nyert jelentősebb 
teret a politikai gondolkodásban. Jószerivel csak 1849 áprilisában, a Függetlenségi Nyilatkozat országgyülési vitája során bukkant fel Debrecenben. Előzményének tudhatjuk a Ferenc József császár által 1849. március 4-én kiadott olmützi ,,alkotmányt”, amely Magyarországot önállóságától megfosztva koronatartományként sorolta az egységes osztrák birodalomba. Kossuth - válaszul a császár deklarációjára - április 12-én ismertette trónfosztási tervét a Honvédelmi Bizottmány, majd a képviselőház zárt ülése elött, sokan azonban a döntés elhalasztását kérték. Néhányan ugyanakkor kevésnek tartották a trónfosztást, és vele egyidejüleg a köztársaság elfogadtatását is szorgalmazták. Kossuth csitította őket. Az európai kedvezőtlen politikai közvéleményre, elsősorban Párizsra és Londonra hivatkozott. Az országgyülés plénuma április 14-én elfogadta Kossuth indítványát: a Függetlenségi Nyilatkozatot. A magyar országgyülés így deklarálta az ország függetlenségét és a Habsburg-ház trónfosztását. Megkerülte azonban az államforma kérdését, elhalasztotta a döntést, de az államföi tisztségre kormányzó-elnöki megbízatással egyhangúlag Kossuth Lajost választották meg. Valójában tehát a külpolitikai megfontolások és a belső viszályok miatt felemás, illetve félmegoldás született. Az országgyülés kimondotta ugyan a Habsburg-ház trónfosztását, új államföi tisztséget is alkotott, de nem szüntette egyben meg a királyság államformáját s nem deklarálta a köztársaságot. A nyilvánvaló ellentmondás radikális feloldására néha-néha még találkozunk egyes kísérletekkel, ezek azonban elszigeteltek és hatástalanok maradtak. 1849. május 4-én például Sillye Gábor képviselő Hajdúböszörmény város határozata szerint a köztársaság kikiáltására tett javaslatot, határozathozatalra azonban nem került sor. Hasonló sorsra jutott Hajdúnánás 1849. május 12-i határozata is.

A Függetlenségi Nyilatkozattal szemben akkor - az elözmények ismeretében ez természetes is - jelentősnek tekinthető személyiség nem tiltakozott. A megjelent véleményeket többnyire fenntartás nélkül, lelkesen üdvözölték. Ám olyanok is akadtak, akik e történeti jelentőségü döntés előnyeiről, illetve hátrányairól elmélkedtek.

Jókai Mór az Esti Lapokban megjelent, Április 14-e címü írásában olvashatjuk: ,Jegyezze föl a história e napot, a magyar nép jövő élete e naptól fogja számítani új esztendejét. E nagy napot nagy tettek kövessék. Legnagyobb tett legyen az tölünk, hogy egyetértsünk: hogy pártokra ne szakadjunk. Ellenségeink erejét ez által nem növeltük s hisszük: hogy a magunkét sem fogyasztottuk. Mi a békét szerettük, de nem a halál alakjában, s ha a nemzet életének egyedüli feltétele az: hogy küzdjön, legyen bármilyen hosszú a küzdelem, elfogadjuk...”

Kossuth a döntés szükségességét hangoztatva kísérletet tett a nagyhatalmak megnyerésére. Békét és barátságot ígért számukra az önálló Magyarország részéről. „A magyar nemzet ezen határozata nem szenvedélyből, túlbizakodásból, avagy forradalmi viszketegből eredett, hanem ... jogszerü kénytelenség volt..."

A radikális, de kivételes realitást tanúsító Csányi László április 24-iki, Kolozsvárról Kossuthoz írott levelében óv az elbizakodottságtól s a leskelődő veszélyekre figyelmeztet. „A fekete leves bizonyosan hátra van s csak ezután tálaltatik fel - de a vonaglás órái rövidek -, a kérdés jobbra vagy balra egy pár hó alatt lényeges részében eldől." Tudjuk, Csányi sorait, balsejtelmét igazolta a történelem.

Kossuth már törökországi emigrációja idején kidolgozta Alkotmánytervét, amelyben az államszerkezet egészébe illesztve megtalálhatjuk a nemzetiségi kérdés megoldására irányuló javaslatát is. Különösképpen az utóbbit később tovább csiszolta, alakította, és 1862-ben Dunai Szövetség címmel tette közzé. Az 1851-ben Kütahyában keltezett Alkotmánytervében - ezt is tovább formálta - a polgári Magyarország tervét vázolta fel.

Ez az Alkotmányterve feltünően hasonlít az 1831. évi belga alkotmányra. „Fő alapelv - írta - a népfelség vagy is önkormányzat. Nép alatt értem a honpolgárok egyetemét." Tételesen felsorolta a szabadságjogokat, a gondolat, a sajtó szabadságát, a lelkiismereti - egyesületi, 
vallási - szabadságot, az egyházi, nemzetiségi - közösségi - önkormányzatot. Részletezi a hatalmi ágak szerkezetét, és pontosan meghatározza feladatkörüket: „A törvényhozó hatalmat az országgyülés gyakorolja. Az országgyülés két házból áll. A népképviselők házából s a senatusból. A népképviselők közszavazat útján választó kerületenként választatnak. A senatus tagjait pedig a megyegyülések választják. Minden megye két senatort küld. Népképviselők és senatorok küldőik által visszahívhatók mindenkoron. A törvény meghatározza a visszahívás módját." A törvényeket a parlament két háza hozza, de kihirdetésük előtt a felállítandó alkotmányszék azokat alkotmányos szempontból átnézi s kijelenti, alkotmányosak-e vagy nem. Az alkotmányőrszék tagjait a senatus nevezi ki, nem lehetnek a törvényhozás tagjai, nem mozdíthatók el tisztségükböl, s lemondásuk után ,sem viselhetnek kormánykinevezéstől függő hivatalt".

Az Alkotmányterv a végrehajtó hatalommal és a kormánnyal kapcsolatban az 1849. áprilisi Függetlenségi Nyilatkozattal összhangban vallja, hogy „az ország szerkezete megállapításában a nemzet kész legyen az európai viszonyok igényeit figyelembe venni”. Eszerint Magyarország államformája alkotmányos monarchia vagy köztársaság lehet. Mindkét államforma szerkezetével, működésével kapcsolatban kifejti véleményét.

„Ha monarchicus lenne a kormányforma - írta -, a nádori méltóság megtartására fontosságot helyezek. Országgyülés által választandó vegyes ülésben, minden tag egyenlő szavazattal bírandván. (Szeretem, ahol lehet, megtartani a historiai alapot.) A nádor egész életére lenne választandó...

Ha ellenben (mit óhajtok, hogy a körülmények megengedjenek, az európai haladás különben is a democratiai kormányformát mutatván ki a jövendő postulatumaul), ha ellenben köztársasági országlat fogadtatik el, a végrehajtó hatalom főnöke közszavazat útján leszen az országpolgárok összes egyeteme által választandó...

$\mathrm{Az}$ ország főnökének címéül (ismét historiai alapon) a kormányzó (gubernator) címet ajánlom. Hivatal ideje hat vagy kilenc év."

Említettem már, hogy Kossuth különös érdeklődéssel kísérte az Egyesült Államok 1776. évi alkotmányát. A forradalom és szabadságharc leverése után is az Államokhoz fordult, ,,a szabadság dicső hazájához”, a „bátrak honához”, a földhöz, ahol ,az emberiség nagy szíve dobog”.

1851. december 4-től 1852. július 14-ig az Egyesült Államokban tartózkodott. Számos előadást tartott, főleg a New York és Washington körüli városokban, továbbá Indiana, Ohio, New Orleans, Atlanta, Virginia, Massachusetts és más államokban. Columbusban mondotta: „Korunk szelleme a demokrácia. Mindent a népért és mindent a nép által. Semmit a népről a nép mellőzésével. Ez a demokrácia.” Több alkalommal is hangoztatta: „Az Egyesült Államok igazán demokratikus köztársaság, ideális szövetségi rendszer.” Ö azonban az államszövetség, és nem az államok szövetségének híve.

Előadókörútján felkeltette a magyar ügy iránti rokonszenvet, mindenütt kivételes fogadtatásban részesítették. Lincoln mondotta a tiszteletére rendezett fogadáson: „Mi a magyarországi Kossuth kormányzóban a kontinensen a polgári és a vallási szabadság ügyének a legérdemesebb és legkiválóbb képviselőjét látjuk. Amiért ő és nemzete harcolt mindaddig, amíg egy idegen zsarnok a természeti és a nemzeti törvények legszentebb elveit erőszakot elkövető fegyveres beavatkozása le nem taposta, az a szabadság barátai által mindenütt, de legkivált az Egyesült Államok népe által drágának tartott alapelvek ügye.”

Több támogatást azonban nemigen kapott. Még rosszabbul járt III. Napóleonnal, Mazzininek pedig nem volt lehetősége a segítségadásra.

Mindez azonban már meghaladja előadásom témáját. 